\title{
IAMJ
}

INTERNATIONAL

AYURVEDIC

MEDICAL JOURNAL

ISSN: 2320-5091

Impact Factor: 6.719

\section{GLOBALIZATION OF AYURVEDA}

\author{
Avvinish Narine ${ }^{1}$, Fatemeh Moazzami Peiro², Gopesh Mangal ${ }^{3}$ \\ ${ }^{1}$ PG Scholar, Panchkarma Department NIA Jaipur, Rajasthan, India (Citizen of Trinidad and Tobago). \\ ${ }^{2}$ BAMS, NIA Jaipur, Rajasthan, India (Citizen of Iran). \\ ${ }^{3}$ Associate Professor, Panchkarma Department NIA Jaipur, Rajasthan, India.
}

Corresponding Author: dr.anarine@icloud.com

https://doi.org/10.46607/iamj2609122021

(Published Online: December 2021)

Open Access

(C) International Ayurvedic Medical Journal, India

Article Received: 25/11//2021 - Peer Reviewed: 10/12/2021 - Accepted for Publication 11/12/2021

Check for updates

\begin{abstract}
Globalization is the process of interaction and integration among people, companies, and governments worldwide, causing growth in international trade and the exchange of ideas and culture. Ayurveda, the Science of Life, was in previous times, only available in the Indian subcontinent and surrounding countries. But with the advancement of time and technology, awareness of the great Science of Ayurveda has spread globally, and many nations now seek to explore this science. In 1978 the 'Alma-Ata-Declaration' by the WHO stated their evaluation and promotion of traditional medicine ${ }^{1}$. Which, after many policies and committees, eventually led to the birth and mainstreaming of the AYUSH Ministry in 2003. Today the globalization process of the Ayurveda system of medicine has reached many nations, due to the efforts of the AYUSH Ministry, especially in the Covid-19 pandemic situation the role of Ayurveda and AYUSH Ministry guidelines to boost immunity and the preventative aspect globally is something worth mentioning. In this article, an overview will be given as to what is being done globally, with a special focus on the status of Ayurveda in Trinidad and Tobago and Iran (Persia).
\end{abstract}

Keywords: AYUSH, Ayurveda, Globalization, MoU, WHO.

\section{INTRODUCTION}

Globalization is primarily an economic process of interaction and integration between nations that is associated with the exchange of social and cultural aspects as well as technology and knowledge. Globalization is the process of international integration arising from the interchange of the world's views, products ideas, and other aspects of culture. ${ }^{2}$ With this view, Ayurveda has been introduced in advanced countries in the 
past few decades. And in recent times, those countries have begun to practice the Ayurveda system of medicine. Since the globalization process began, many other countries are interested in this system of medicine. As such, the AYUSH ministry in India has been set up and has been making contact with countries that share relations with India. A special branch of AYUSH that deals with the spreading of Indian culture worldwide, in specific, Ayurveda, is the Indian Council for Cultural Relations (ICCR). The ICCR is located in New Delhi and has contact with many countries worldwide, offering various courses, including Ayurveda to Nationals of those countries to participate and take the knowledge to their own land. The ICCR has been educating people for as long as relations began and one such scholarship is the Bachelor of Ayurvedic Medicine and Surgery (BAMS). The BAMS course sets to educate those nationals about the system of Ayurveda and then take it to their home country for the practice of this system of medicine there.

\section{History of AYUSH}

The Ministry of AYUSH was formed on the 9th day of November 2014. Earlier it was known as the Department of Indian System of Medicine and Homeopathy (ISM\&H) which was created and established in March 1995 and then later renamed as Department of Ayurveda, Yoga and Naturopathy, Unani, Siddha and Homeopathy (AYUSH) in November of 2003, with a specific view to provide focused attention for the development of Education and Research in Ayurveda, Yoga and Naturopathy, Unani, Siddha and Homeopathy. AYUSH's guidelines for establishing Ayurveda/ Yoga/ Unani/ Siddha/ Homeopathy Chairs in foreign universities/ institutions. The Ministry establishes Academic Chairs in the foreign universities/institutes in consultation with Indian Missions abroad. The institute level Memorandum of Understanding (MoU) for the establishment of such Chairs by the Ministry is signed between the Institute/ Council functioning under the Ministry and the concerned host Foreign University(s)/ Institute.

\section{Some of the Objectives include:}

- To create awareness abroad about the strengths of AYUSH systems in the management of various disease conditions and to develop interdisciplinary linkages.

- To develop academic programs in AYUSH systems of different duration for the students in the foreign educational institutes.

- To promote academic and collaborative research activities on AYUSH Systems abroad.

\section{Achievements of AYUSH Ministry}

The Department of AYUSH has supported many international conferences and seminars in collaboration with the local Indian Missions and Universities abroad. Experts from AYUSH are appointed as resource persons to events for facilitating the training and education of AYUSH Systems in these countries. As part of its continuous efforts to promote these systems of medicine globally, India has signed pacts with 23 countries for cooperation in the field of Traditional Medicine so far. The countries include Nepal, Bangladesh, Hungary, Trinidad \& Tobago, Iran, Malaysia, Mauritius, Mongolia, Turkmenistan, Myanmar, Germany (Joint declaration), Sao Tome \& Príncipe, Equatorial Guinea, Cuba, Colombia, Japan (MoC), Bolivia, Gambia, Republic of Guinea, China, St. Vincent \& The Grenadines and Suriname. ${ }^{3}$ Furthermore, 22 MoUs have been signed for undertaking collaborative research in AYUSH systems of medicine with various foreign universities in Germany, the United Kingdom, Canada, United States, Argentina, Israel, Brazil, Australia, Austria, Tajikistan and Ecuador to conclusively prove the benefits of Ayurveda. Also, 13 MoUs for setting up AYUSH Academic Chairs have been signed with foreign institutes in Hungary, Trinidad \& Tobago, South Africa, Thailand, Russia, Indonesia, Slovenia, Armenia, Latvia, Argentina, Malaysia, Bangladesh and Mauritius. The Ministry of AYUSH has set up 33 AYUSH Information Cells in 31 countries to disseminate authentic information about the AYUSH systems of Medicine. The World Health Organisation announced recently, that it will set up a Global Centre for Traditional Medicine in India, with confidence that just like the country has emerged as the 'Pharmacy of the World', the WHO institution will become the centre for global wellness. Ayurveda is recognized and practised in only a few of the previously listed 
countries viz: Nepal, Sri Lanka, Bangladesh, Bhutan, Mauritius and Hungary. Ayurveda or a similar type system of medicine is recognized in Thailand, Myanmar, Indonesia etc.

\section{Method of Implementation:}

Establishment of Chair will be on the terms and conditions as mentioned below: -

- Tenure: The Chair would be initially set up for a period of one year, extendable up to three years.

- Location: Institute/ University nominated by the Host Country.

- Selection: Final selection of the faculty to be deputed from India will be made with mutual consultation with the foreign University/ Institute.

List of Some Educational Ayurveda Organizations Under the AYUSH Ministry:

1. National Institute of Ayurveda (NIA), Deemed to be University (De Novo), Madhav Vilas Palace, Jorawar Singh Gate, Amer Road, Jaipur-302002 (Rajasthan).

2. Institute of Post-Graduate Training and Research in Ayurveda, (I.P.G.T.R.A.), Gujarat Ayurved University, Jamnagar-361008 (Gujarat)

3. All India Institute of Ayurveda (AIIA), Gautam Puri, Sarita Vihar, New Delhi-110076.

List of Some Educational Ayurveda Organizations Under the AYUSH Ministry with seats for foreign candidates:

1. National Institute of Ayurveda (NIA), Deemed to be University (De Novo), Madhav Vilas Palace, Jorawar Singh Gate, Amer Road, Jaipur-302002 (Rajasthan).

2. Institute of Post-Graduate Training and Research in Ayurveda, (I.P.G.T.R.A.), Gujarat Ayurved University, Jamnagar-361008 (Gujarat).

3. Chaudhary Brahm Prakash Ayurved Charak Sansthan, Khera Dabar, Najafgarh, New Delhi110073.

List of Some Ayurveda Research Organizations Under the AYUSH Ministry:

1. Central Council for Research in Ayurvedic Sciences (CCRAS), Jawahar Lal Nehru Bhartiya Chikitsa Avum Homoeopathy, Anusandhan
Bhavan, 61-65, Institutional Area, Opposite 'D' Block, Janakpuri, New Delhi- 110058.

Statutory Councils for Regulation of Education and Practice:

1. Central Council for Indian Medicine (CCIM), Jawahar Lal Nehru Bhartiya Chikitsa Avum Homeopathy, Anusandhan Bhavan, 61-65, Institutional Area, Opposite 'D' Block, Janakpuri, New Delhi110058.

\section{Materials \& Methods}

Various literature concerning the AYUSH Ministry and its functions were reviewed, as well as literature about the globalization of Ayurveda was consulted and reviewed carefully in the writing of this review article. Some articles were excluded as they were personal opinions of the respected authors.

\section{Status of Ayurveda in Trinidad and Tobago ${ }^{4}$}

In 2012, at the invitation of the former Prime Minister of India; the now-former Prime Minister of Trinidad \& Tobago visited India and was accompanied by a high-level delegation comprising of seven Cabinet Ministers. During this visit, many memorandums of understanding (MoU) were signed, the one significant in relation to this article is the $\mathrm{MoU}$ on 'Co-operation in the field of Traditional Medicine and for setting up a Chair of Ayurveda in the University of the West Indies (UWI). In order to promote and disseminate information on Ayurveda in Trinidad \& Tobago, an AYUSH information centre, maintained by the AYUSH Ministry was opened in the High Commission by the former Minister of Local Government. In October of 2012, the Hon. Minister of Health \& Family Planning (AYUSH) visited Trinidad \& Tobago, in the context of bilateral co-operation in the area of traditional medicine namely 'Ayurveda'. While there, he inaugurated the AYUSH information centre and dedicated it to the people of Trinidad \& Tobago. Trinidad \& Tobago (T\&T) is a Twin Island Republic Nation located in the West Indies. T\&T distinguishes itself by the fact that it comprises different races and ethnicity which co-exist harmoniously. The national general population comprises people originating from the following countries: India, China, Europe, Syria/Lebanon and South America. It is a multi-cultural and 
multi-ethnic society. The Mission in T\&T has been engaged in active cultural diplomacy through its Cultural Wing, Mahatma Gandhi Institute of Cultural Cooperation (MGICC), which was set up in January 1997 under a Bilateral Cultural Exchange Programme. Its function is to promote bilateral cultural cooperation primarily in the field of arts and culture, both at the Government and NGO levels, through its cultural and teaching activities by the India-based teachers in Indian classical music and dance, among other things. The MGICC offers annual scholarships under ICCR's General Cultural Scholarship Scheme and in this Ayurveda, Scholarships have also been introduced recently. The Mission in collaboration with the University of West Indies has set up three Chairs viz. (i) Chair of Hindi; (ii) Chair of Contemporary Indian Studies; and (iii) Chair of Ayurveda. Currently, in Trinidad and Tobago, the citizens are aware of Ayurveda and its various treatment modalities but the implementation of this system of medicine is still in its initial phases. With growing demand and an increased interest in natural treatment, Ayurveda seems to have a very promising future there.

\section{Status of Ayurveda in Iran}

On May $23^{\text {rd }}, 2016$, India and Iran have signed MoU between the Indian Council for Cultural Relations (ICCR) and Islamic Culture and Relations Organizations of the IR Iran ${ }^{5}$. The Union Cabinet chaired by Hon. The Prime Minister of India has given its ex post facto approval for the $\mathrm{MoU}$ in the field of health and medicine which was signed on February $17^{\text {th }}, 2018$, during the visit of Iranian President to India ${ }^{6}$. The main areas of cooperation include exchanging experience and training of doctors and other health professionals, assistance in the development of the human resource, setting up healthcare facilities and regulating pharmaceutical, medical devices and cosmetics. It also includes cooperation in the field of medical research, new technologies and knowledge-based initiatives, public health, and sustainable development goals (SDGs) among others. A working group will be set up to elaborate on the details of cooperation and to oversee the implementation of this MoU. The other MoU signed in the field of traditional systems of medicine will enhance bilateral cooperation and will be of immense importance to both countries considering their shared cultural heritage. It is known that India is blessed with well-developed systems of traditional medicine including medicinal plants, which hold tremendous potential in the global health scenario. India and Iran share several common features in their language, culture and traditions, and also share a common legacy of using herbal medicines. Both countries have huge biodiversity and are home to rare medicinal plants which are frequently used in traditional systems of medicine.

1. MoUs for Cooperation in field of Traditional Medicine, Iran (17 ${ }^{\text {th }}$ February 2018).

2. India-Iran Cultural Exchange Programme.

3. MoU between the Ministry of External Affairs (MEA) of India and the Ministry of Foreign Affairs (MoFA) of Iran on Policy Dialogue between Governments and Interaction between think tanks.

4. MoU between Foreign Service Institute, MEA and the School of International Relations, Iran's MoFA.

5. Implementation Protocol between the Department of Science and Technology, Ministry of S\&T and Iran's Ministry of Science, Research and Technology on Cooperation in the Fields of Science and Technology.

6. MoU between Indian Council for Cultural Relations and Islamic Culture and Relations Organizations of the IR Iran. $\left(22^{\text {nd }}-23^{\text {rd }}\right.$ May 2016).

Iran has been one of the countries of high importance to India from times immemorial. The interaction between Iran and India has been such that both have been affected by each other. The two countries have had good relations in the past. India-Iran relations span millennia marked by meaningful interaction. The two countries shared a border till 1947 and share several common features in their cultural, political, religious, economic, and linguistic relations. The age-long historical relations between the Iranians and the people of the Indian subcontinent date back to a very remote past. In the splendid civilization of Mohenjo-Daro and the Sindh Valley which flourished between 2500 and $1500 \mathrm{BC}$, there are visible signs of relationship with 
the Iranian civilization ${ }^{7}$. Such relations and cultural interactions continue to exist even in the colonial era of the British ruling over India. The impact of such relations is still visible in the similarity of the beliefs, myths, theosophy, and literature of both countries as well as the books inherited from the past. The study of the relationship between these two nations (Iran and India) is an interesting job that will lead to further clarification of such relationships and increase our knowledge of the past. As per the Iranian people and government connection with Indian culture and traditional medicine and the MoU between two countries Ayurveda is in the growing phase in Iran, there is great improvement between the two countries as per academic education of Ayurveda in the international arena.

\section{DISCUSSION AND CONCLUSION}

The AYUSH Ministry of India is fully dedicated to the dissemination of Ayurveda on the Global platform. Since its inception, the Ministry has displayed their unwavering support by signing MoUs with various countries internationally, over the years and continue to do so with plans to enroll even more countries in the future. Another aspect of their initiative to spread Ayurveda globally, the various Ayurveda courses offered by the ministry through the ICCR is awarded to deserving scholars around the world, in various scholarship schemes. These scholarship schemes are ongoing with an enrollment of the scholars taking place yearly. This alone shows the commitment of the government of India and the Ministry to promote Ayurveda globally. Mentioned in this article are only two of the countries where the Ministry of AYUSH is making headway in the arena of promoting Ayurveda there.

\section{REFERENCES}

1. "Alma Mater Declaration" by WHO; available at https://www.euro.who.int/data/assets/

pdf_file/0009/113877/E93944.pdf; [Accessed on 20th August 2020 at 10:10 pm].

2. "Globalization" Wikipedia definition available at: https: //en.wikipedia.org/ wiki/ Globalization; [Accessed on 20th August 2020 at 10:10pm].
3. "Ayurveda: India for enhancing global co-operation" by Ayurveda Admin; available at https://www.ayurvedamagazine.org/ayurveda/articledetail/643/AyurvedaIndia-for-enhancing-global-co-operation; [Accessed on 23rd August 2020 at 10:33 pm].

4. "Foreign Relations: India- Trinidad and Tobago" available at: http: //mea.gov.in /Portal/ Foreign Relation/ India-Trinidad_Tobago_Relations.pdf [Accessed on 22nd August 2020 at 11:33am].

5. "Iran and India in 2016 / PM Modi's trip to Iran" by Ahmad Ali Khalilnejad; available at https://www.irna.ir/news/82355148/ [Accessed on 15th July 2021 at 21:35].

6. "Tehran and New Delhi signed 15 cooperation documents" by ASR Press Agency; available at https://www.asrpress.ir/fa/news/7902/ [Accessed on 16th July 2021 22:20].

7. Nehru Jawaharlal, (1946), The discovery of India, Rekha Printers PVT Ltd, New Delhi.

\section{Source of Support: Nil Conflict of Interest: None Declared}

How to cite this URL: Avvinish Narine et al: Globalization Of Ayurveda. International Ayurvedic Medical Journal \{online\} 2021 \{cited December 2021\} Available from: http://www.iamj.in/posts/images/upload/3087_3091.pdf 